класс бетона этого состава в 28 суток будет В22,5. Поскольку еще бетон не достиг возраста 28 суток окончательные выводы делать рано.

В дальнейшем планируется продолжение работы с добавкой ЦМИД-4 с различными расходами цемента для достижения оптимальных результатов по прочности, удобоукладываемости бетона и снижение расхода цемента.

\title{
Спекание порошка восстановленной руды Ленского рудного поля Республики Саха (Якутия) с алюминием
}

Прядезников Б.Ю., ведущий инженер, E-mail: pryadeznikov@bk.ru; Тарасов И.П., магистрант, E-mail: tarasov19411945@mail.ru Северо-Восточный федеральный университет, 2. Якутск

Научный руководитель: к.т.н., доцент Тарасов П.П.

Исследование закономерностей спекания систем на основе алюминия приобретает большое практическое значение в связи с развитием порошковой металлургии сплавов на его основе. Известно, что введение твердых тугоплавких частиц второй фазы в пластичный алюминий повышает его прочность, твердость, жаропрочность и износостойкость при одновременном снижении коэффициентов трения и термического расширения [1. С. 4]. Использование алюминидов интерметаллидных соединений алюминия с переходными металлами в качестве упрочняющей фазы - является перспективным способом создания нового поколения функциональных материалов на основе алюминия.

В связи с этим особую актуальность приобретает изучение процессов, происходящих при жидкофазном спекании, их вклад в объемные изменения порошковых тел с взаимодействующими компонентами. Исследование процессов спекания алюминия с добавками порошков переходных металлов представляется научной проблемой, тесно связанной с практической задачей создания нового поколения композитов на основе алюминия.

В настоящее время сотрудниками Института физико-технических проблем им. В.П. Ларионова СО РАН и Северо-Восточного федерального университета им М.К. Аммосова проводится совместная научно-исследовательская работа по прямому восстановлению водородом железной руды Ленского рудного поля [2. С. 68]. Цель работы - разработка технологии прямого восстановления водородом железной руды, исследование влияния режима термообработки, содержания и химического состава добавки на структуру и свойства спеченных сплавов на основе алюминия.

\section{Материалы и методика эксперимента}

В работе исследованы образцы из проявления железомарганцевых руд в верховья реки Мундуруччу (левый приток р. Амга) Ленского рудного поля Республики Саха (Якутия). 
Метод прямого восстановления металлов водородом, как технологический процесс, заключается в нагреве подготовленной, то есть измельченной до определенной крупности, руды в среде газа-восстановителя, в данном случае водорода. Восстановление производилось при температуре $950{ }^{\circ} \mathrm{C}$ в течении 40 мин. В восстановленном продукте наблюдается припекание частиц друг к другу. Для устранения агломерации частиц производилось дополнительное измельчение на вибрационной мельнице [3. С. 307].

При получении спеченных композитов на основе алюминия использовались стандартный порошок алюминия марки АСД-1 (ТУ 48-5-226-87), порошок железа марки ПЖВ1 (ГОСТ 9849-86), порошок восстановленной руды крупности -0,063 мм.

Порошки смешивались в смесителе типа «пьяная бочка» в течение 2 ч. Предварительно их подвергали просушиванию в вакуумной сушилке СНВС по режиму: 1,5 ч при $150{ }^{\circ} \mathrm{C}$ в условиях форвакуума. Формование цилиндрических образцов диаметром и высотой по 10 мм производилось в стальной пресс-форме, начальная пористость составляла 20 \%. Спекание осуществлялось в вакуумной печи СНВЭ при давлении $0,1 \cdot 10^{-3}$ Па и температуре от 700 до $900{ }^{\circ} \mathrm{C}$.

Плотность спрессованных образцов определялась геометрическим способом. В случае потери или искажения правильной геометрической формы применялся метод гидростатического взвешивания.

Твердость по Бринеллю оценивалась согласно ГОСТ 9012-59 на приборе Omag Affri 206RTD.

\section{Результаты и обсуждение}

Согласно результатам проведенных ранее исследований порошковых систем алюминий - переходной металл (Al-Ni, $\mathrm{Al}-\mathrm{Ti}, \mathrm{Al}-\mathrm{Fe}, \mathrm{Al}-\mathrm{Cu})$ наибольший научный и практический интерес представляет область концентраций металла-добавки до 20 ат.\%. С учетом этого были исследованы сплавы с содержанием 26,8 и 22,8 вес.\%. Для выявления влияния на процесс жидкофазного спекания химического состава легирующей добавки в работе использовались стандартный порошок железа марки ПЖВ1 и порошки восстановленной руды двух типов: порошок восстановленной руды и порошок восстановленной руды, прошедшей дополнительное обогащение, заключающееся в сухом доизмельчении с последующей магнитной сепарацией водной суспензии порошка и сушке при температуре $120^{\circ} \mathrm{C}$ до воздушно-сухого состояния.

Большое влияние на объемные изменения порошковых тел оказывает режим спекания. Для исследуемой системы Al-Fe характерным является выделение большого количества тепла при образовании интерметаллидов. Тепловой взрыв при появлении жидкой фазы может вызвать резкие изменения объема прессовки и потерю формы брикета. Кроме того, для устранения влияния адсорбированных и находящихся в порах газов на процесс спекания требуется дегазация брикета.

Для предотвращения потери формы необходимы регулирование скорости нагрева и проведение твердофазного отжига при температуре ниже температуры появления жидкой фазы. При твердофазном отжиге на поверхности частиц железа за счет диффузии атомов алюминия образуется тугоплавкий интерметаллидный слой. При дальнейшем спекании этот слой замедляет процесс сплавообразования и уменьшает скорость выделения теплоты в момент появления жидкой фазы. При достаточном количестве частиц тугоплавкой добавки в ходе твердофазного отжига образуется твердофазный скелет прессовки, обеспечивающий постоянство формы порошкового 
тела при жидкофазном спекании.

Исходя из вышесказанного, спекание образцов на основе порошка алюминия марки АСД-1 проводили по режиму с дегазационным твердофазным отжигом при $t=$ $500{ }^{\circ} \mathrm{C}$ в течение 30 мин, после чего температура печи поднималась до температуры спекания $t_{\text {сп }}$ со скоростью $15^{\circ} \mathrm{C} /$ мин (рис. 1).

Установлено, что образцы с легирующей добавкой порошка железа марки ПЖВ1 испытывают усадку во всем диапазоне температур спекания (рис. 2 а, 2 б). Остаточная пористость образцов с содержанием железа 22,8 и 26,8 вес.\% находится на уровне 10\%. Начиная с температуры $700{ }^{\circ} \mathrm{C}$ наблюдается искажение формы прессовок, приводящее при температуре спекания $800{ }^{\circ} \mathrm{C}$ к полной потере геометрической формы образцов. Образцы с добавкой восстановленной руды сохраняют форму практически во всех исследованных диапазонах изменений температуры спекания и содержания добавки.

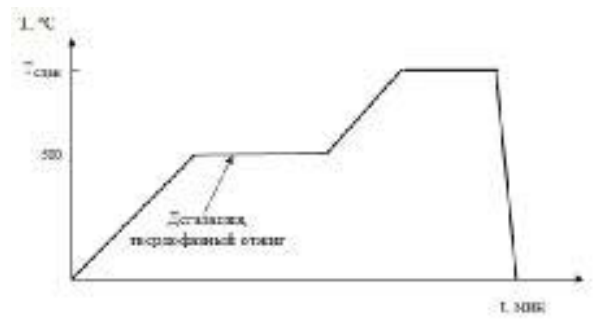

Рис. 1. Режим спекания порошковых тел

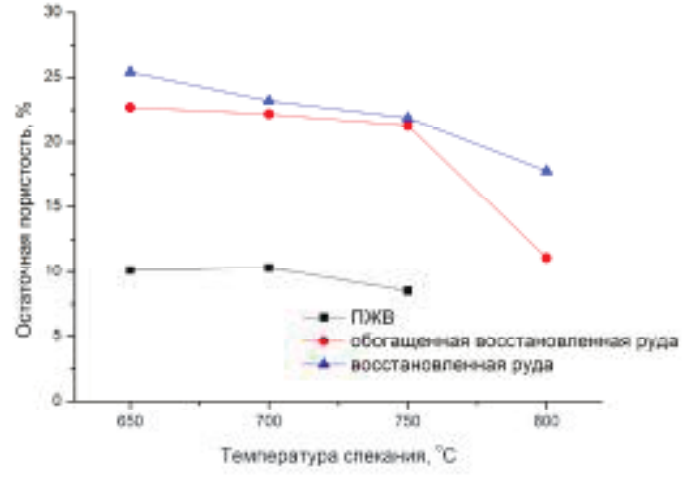

a)

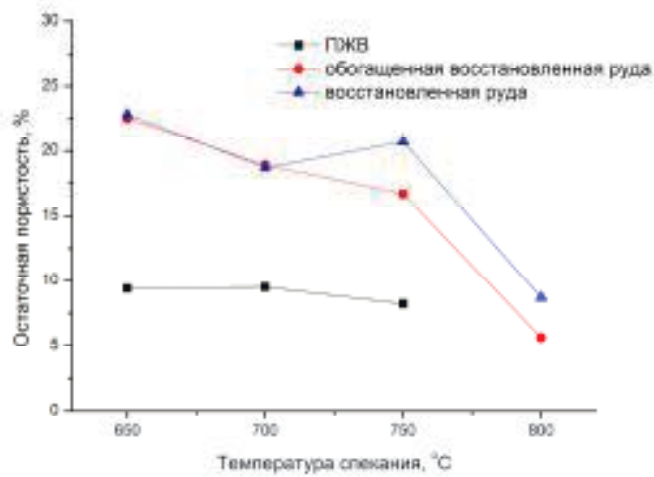

б)

Рис. 2. Зависимость остаточной пористости спеченных сплавов от температуры спекания. Содержание добавки 26,8 вес \% (а) и 22,8 вес \% (б)

Для образцов с добавкой восстановленной руды является характерным более низкая степень усадки при спекании, при температурах спекания до $750{ }^{\circ} \mathrm{C}$ наблюдается рост объема порошковых тел (рис. 2 а, 2 б). Наблюдается выпотевание жидкой фазы на поверхности образцов, что свидетельствует о низкой смачиваемости частиц твердой фазы жидкой, и как следствие, затруднению процесса жидкофазного спекания. Повышение температуры спекания до $800{ }^{\circ} \mathrm{C}$ приводит к уменьшению остаточной пористости прессовок, устранению выпотевания жидкой фазы на поверхности образцов, что свидетельствует о лучшей смачиваемости твердой фазы жидкой, что можно объяснить прохождением алюмотермической реакции довосстановления поверхностных оксидных пленок на частицах восстановленной руды.

При этом, снижение концентрации добавки до 22,8 вес.\% приводит к уменьшению остаточной пористости спеченных композитов. Практически во всем 
диапазоне температур спекания наблюдается лучшая спекаемость брикетов, где в качестве легирующей добавки применялся порошок восстановленной руды с дополнительным обогащением.

Остаточная пористость спеченных сплавов является одним из основных факторов, влияющих на структуру и механические свойства порошковых материалов. Результаты измерения твердости спеченных образцов приведены на рис. 3 а, и 3 б. Более высокая остаточная пористость спеченных сплавов с добавкой восстановленной руды, по сравнению с композитами с добавкой порошка ПЖВ1, приводит к значительно более низким показателям твердости сплавов.

Увеличение температуры спекания уменьшает данный разрыв, особенно при со

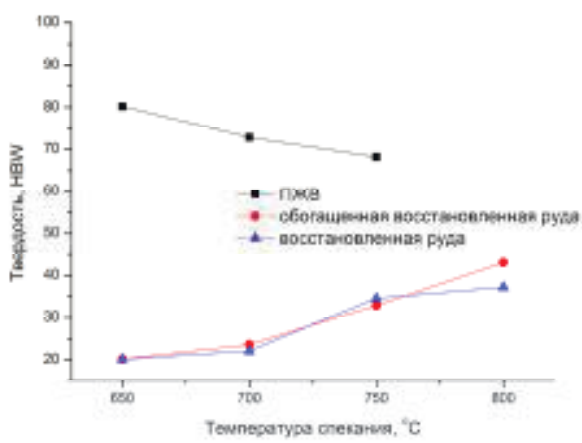

a)

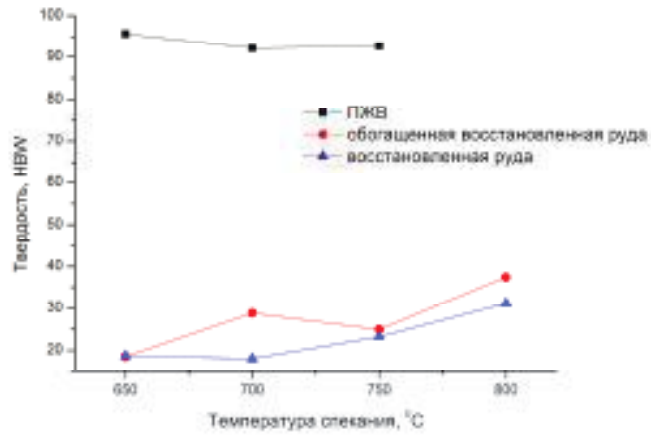

б)

Рис. 3. Зависимость твердости спеченных сплавов от температуры спекания. Содержание добавки 26,8 вес \% (а) и 22,8 вес \% (б)

держании добавки восстановленной руды 22,6 вес.\% (рис. 3, б). Применение в качестве легирующей добавки порошка восстановленной руды с дополнительным обогащением также приводит к повышению твердости образцов. Представляется перспективным проведение дальнейших исследований при меньших содержаниях легирующей добавки.

\section{Заключение}

Получены спеченные порошковые материалы на основе алюминия с добавкой порошков восстановленной руды. Установлено, что повышение температуры спекания приводит к уменьшению остаточной пористости прессовок, устранению выпотевания жидкой фазы на поверхности образцов, что свидетельствует о лучшей смачиваемости твердой фазы жидкой, что можно объяснить прохождением алюмотермической реакции довосстановления поверхностных оксидных пленок на частицах восстановленной руды.

\section{Список литературы:}

1. Тарасов П.П. Структура и свойства спеченных сплавов системы алюминийхром / П.П. Тарасов, А.С. Сыромятникова // Известия высших учебных заведений. Порошковая металлургия и функциональные покрытия. - 2015. - №3. - С. 4-10.

2. Рентгеноспектральные и морфологические исследования продуктов дробления и прямого восстановления водородом железных руд Ленского рудного поля Республики Саха (Якутия) / П.П. Тарасов, Б.Ю. Прядезников, П.П. Петров, К.В. Степанова // Наука и образование. - 2016. - №3 (83). - С. 67-75.

3. Влияние отжига в среде водорода на свойства дробленой железомарганцевой 
руды / Тарасов П.П., Прядезников Б.Ю., Петров П.П. и др. // Хладостойкость. Новые технологии для техники и конструкций Севера и Арктики: труды Всероссийской конференции с международным участием, посвященной 70-летию профессорамеханика, д.т.н. А.В. Лыглаева. - Якутск, 2016. - С.306-310.

\title{
Анализ отказов технических средств тепловозов за 2014-2016 годы на Тындинском регионе Дальне-Восточной железной дороги
}

\author{
Руссов Д., Моисеев Н., студенты, \\ БАмИЖТ - (ф) ДВГУПС в г. Тында \\ E-mail: bamigt.makarov@mail.ru
}

Научный руководитель: стариий преподаватель Смольянинова И.А.

Анализ отказов технических средств за период 2014-2016 годы показывает «слабые» места по ремонту и обслуживанию тепловозов по Тындинскому региону. Причинами возникновения событий в пути следования чаще всего выступают отказы технических средств в части работы дизеля, вспомогательного оборудования, экипажной части, электрооборудования и электрических машин.

Для фиксирования и регистрации ОТС на сети ОАО РЖД принята автоматизированная система учета, контроля устранения отказов технических средств и анализа их надежности (КАСАНТ). После разбора, имеющиеся в 1,2,3 категориях, события или отказы относятся за организацией, допустившей в той или иной мере эти факты.

При анализе ОТС за период 2014-2016 гг. можно проследить тенденцию к увеличению или уменьшению, а также выявить наиболее часто происходящие отказы по видам оборудования тепловоза.

По результатам работы системы КАС АНТ за период 2015 года в ТЧЭ Тында поступило 1181 оповещение об отказах технических средств, против 719 случаев за аналогичный период 2014 года. В 2016 году таких случаев было 1109.

В ходе анализа допущенных отказов технических средств на основе данных системы КАС АНТ было установлено, что качество оформления и своевременность расследования производилось в строгом соответствии с распоряжением ОАО «РЖД» от 23.12.2013 № 2852p.

На основании анализа отказов технических средств по ТЧЭ-11 и для предупреждения дальнейшего увеличения ОТС были приняты следующие меры:

- выполнение приемщиками локомотивов, дежурными машинистами инструкторами проверки качества проведения цикловых работы и устранения ранее выявленных замечаний;

- ведение целенаправленной работы по выполнению в полном объёме ТО-1;

- запрет на приемку локомотивов с неустранимыми замечаниями после проведения ТО-2;

- ополнение плана технических занятий темами составленных на основе таблицы мониторинга системы КАС АНТ и анализа работы приборов безопасности. 